\title{
Hvordan Vesten satte fart i hivepidemien i Afrika
}

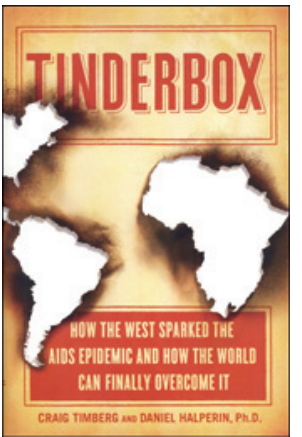

Craig Timberg, Daniel Halperin

Tinderbox

How the west sparked the AIDS epidemic and how the world can finally overcome it. 421 s, ill. New York, NY: Penguin Press, 2012. Pris USD 30 ISBN 978-1-59420-327-5
Forfatterne har arbeidet i flere år med aidsproblemer i Afrika, Craig Timberg som journalist i Washington Post og Daniel Halperin som medisinsk epidemiolog for USA og FN. De er kritiske til Vestens evne til å ta hensyn til de varierende forholdene som finnes i ulike land ved bekjempelse av epidemien.

Forfatterne belyser viktige vitenskapelige, biologiske, epidemiologiske, kulturelle og politiske forhold som antas av betydning for hvordan hiv/aids oppsto og spredde seg.

Tinderbox kan bety både fyrtøy og kruttønne. Både ild og epidemier er avhengig av en rekke tilleggsfaktorer for å spre seg. Boken inneholder tallrike beskrivelser av forholdene i ulike afrikanske land - familieforhold, kulturelle forskjeller, politikk og resultater fra tallrike forskningsprosjekter og hjelpeprogrammer. Det er tre hoveddeler, en epilog og et appendiks med oppsummering av hva forfatterne mener bør gjøres. I tillegg er det 80 sider noter med referanser.

\section{Hundre år med hiv}

Første del omhandler opprinnelsen av hiv, hvor moderne genetiske analyser viser at virus må være overført fra sjimpanser til mennesker i Kamerun en gang mellom 1884 og 1925 - kanskje mest sannsynlig rundt 1908. De første få tilfellene av hivinfeksjon i Kamerun spredte seg via transportveier langs elven til Kinshasa og ga først en begrenset epidemi som utviklet seg eksplosivt pga. faktorer relatert til kolonisering og misjonsvirksomhet fra vestlige land. Smitteoverføring har nok skjedd flere ganger med ulike hivvirus.

Hiv-1 gruppe $\mathrm{M}$ er det viruset som etablerte seg, og som ga opphav til en stor epidemi. Forutsetningen for epidemiutviklingen var vestlig kolonisering med utnytting av ressurser som gummi, diamanter, kaffe, bomull og palmeolje. I tillegg kom etableringen av tekstilfabrikker og gruveindustri som krevde utbygging av transport på elvene og veier og jernbane til lands. Menn som jobbet $i$ lange perioder hjemmefra, ga grunnlag for utvikling av prostitusjon og stadig skifte av seksualpartnere med smitte av stadig flere. Hiv antas spredd til Haiti ved utveksling av eksperter mellom Haiti og Kongo i 1960-årene og derfra videre til homofile i USA.

Halperin legger stor vekt på at misjonsvirksomheten resulterte $i$ at befolkningen sluttet med tradisjonell omskjæring av gutter fordi det ble oppfattet som hedensk. Den største utbredelsen av hiv i Afrika overlapper med områder hvor gutter ikke blir omskåret. Programmer for omskjæring har redusert den heteroseksuelle smitterisikoen for menn med $50-80 \%$.

\section{Politikk, kultur, økonomi}

Andre del handler om betydningen av politikk og kultur. I USA var hivinfeksjon først i hovedsak en epidemi blant homofile og senere også blant stoffmisbrukere, med liten heteroseksuell risiko.

Forebyggingsstrategien i Vesten ble senere overført til Afrika hvor manglende forståelse av lokal kultur og lynne gjorde tradisjonell vestlig tilnærming ineffektiv. I Uganda etablerte imidlertid president Museveni et effektivt program basert på bl.a. gjenoppliving av gamle verdier med tradisjonell polygami.
Ensidig innsats på kondomkampanjer basert på homofile aktivisters innflytelse og eventuelt også økonomiske interesser, mangel på direkte tale både i Vesten og i Afrika, dels for å skåne pasientene og dels av frykt for å stigmatisere pasienter og utsatte grupper, gjorde forebyggingen ineffektiv. Både forskere og ansvarlige for programmer i regi av USA og FN tok lite hensyn til lokal kultur. Rivalisering mellom ulike forskergrupper og organisasjoner, med etter hvert betydelige økonomiske interesser, gjorde at data ble feiltolket og holdt tilbake, og ressursene ble uheldig kanalisert. Ved forebygging av mor-til-barn-smitte satset man på kunstig ernæring etter amerikansk opplegg - uten å ta hensyn til at det dramatisk økte dødeligheten av andre infeksjoner. Dette fikk for eksempel katastrofale følger i forbindelse med flom i Botswana.

\section{Hivepidemiene}

I de siste delene oppsummerer forfatterne effekten av ulike tiltak og betydningen av at hivepidemien ikke ses på som en pandemi, men betraktes som flere ulike epidemier, hvor tiltakene må tilpasses den aktuelle situasjonen. I homofile miljøer står kondomer og endret seksualatferd sentralt, og blant stoffmisbrukere er rene sprøyter viktig.

Ved den heteroseksuelle epidemien i Afrika er omskjæring antakelig et av de mest effektive tiltakene. Begrensning av antall seksualpartner er selvsagt viktig, men må ta utgangspunkt i den lokale kulturen hvor polygami er vanlig. Kondomkampanjer har vært effektivt i prostitusjonsmiljøet i Thailand. Ved smitte fra mor til barn i u-land er eksklusiv brysternæring kombinert med hivbehandling viktig. Testing er viktig ved blodprodukter og for påvisning av hivsmitte, mens det ikke har virkning overfor de som er negative. Hivbehandling som profylakse, behandling av andre seksuelt overførbare sykdommer og bruk av mikrobicider antas å ha begrenset verdi.

Boken kan virke unødig lang med mange gjentakelser. Tallrike intervjuer og skildringer av lokale forhold gjør imidlertid at man får en dypere forståelse for hvorfor epidemien utvikler seg. Forfatterne viser hvor viktig det er å basere hjelpeprogrammer og tiltak på lokale forhold, og det uheldige i å overføre vestens tankegang og kulturforståelse direkte på afrikanske forhold. De illustrerer også uheldige vinklinger som et resultat av at kommersielle interesser og kamp om ressurser kommer inn i bildet. Noen synspunkter er diskutable, men hovedkonklusjonene synes meget vel begrunnet. Boken vil være nyttig og viktig lesning for alle som interesserer seg for hiv/aids-problemene i utviklingsland og særlig i Afrika.

\section{Johan N. Bruun}

Infeksjonsmedisinsk avdeling

Universitetssykehuset Nord-Norge 